Author(s): Roman Horbyk

Source: Kyiv-Mohyla Humanities Journal 3 (2016): 89-103

Published by: National University of Kyiv-Mohyla Academy

http://kmhj.ukma.edu.ua/ 


\title{
Ideologies of the Self: Constructing the Modern Ukrainian Subject in the Other's Modernity
}

\author{
Roman Horbyk \\ Södertörn University, \\ Media and Communication Studies Department
}

\begin{abstract}
Postcolonial theory has recently come under critique as an interpretative scheme applied to Eastern Europe and particularly Ukraine. However, a closer look suggests that the critique applies only to some aspects of the approach, such as a focus on power relations and representations, while the key question should be rephrased as whether the Ukrainian subject was constituted as a colonial subject. A range of empirical material from 1920 S Ukrainian discourses, both Soviet and émigré, is analyzed to shed light on how Ukrainians constructed their subjectivity as "a site of disorder" (Dipesh Chakrabarty), splitting themselves into uncultured peasant masses to be modernized and erased as a voiceless subaltern subject, on the one hand, and modernizing elites, on the other. This split can be understood as an epitome of the colonial condition.
\end{abstract}

Key Words: Ideology, subjectivity, modernity, Ukraine, Interbellum.

\section{Introduction}

A recent discussion in Slavic Review has highlighted the position of Ukraine as the problematic touchstone for postcolonial theory. ${ }^{1}$ On the one hand, Timothy Snyder reconceptualized European history by introducing the perspective on both Nazi and Soviet projects as essentially colonialist and aimed at turning different countries in Europe into colonial possessions. They were driven, Snyder finds, by a dual logic that structured their agenda as simultaneously anticolonial (a liberatory struggle against Jews or the capitalist West) and colonial (expanding territories and strengthening own security at other nations' expense); in the scholar's opinion, this is still the logic that thrusts the ongoing Russian aggression against Ukraine.

This interpretation, however, was criticized by Maria Todorova as only metaphoric when used in the Ukrainian context. ${ }^{2}$ Ilya Gerasimov and Marina Mogilner also found fault with postcolonial approaches in their representation of Ukraine as an object of imperial

$1 \quad$ Timothy Snyder, "Integration and Disintegration: Europe, Ukraine and the World," Slavic Review 4 (2015): 692-707.

2 Maria Todorova, "On Public Intellectuals and Their Conceptual Frameworks," Slavic Review 4 (2015): 708-14. 
contestations rather than as a subject of its own agency. ${ }^{3}$ Yaroslav Hrytsak imparted that Ukraine was seen by Russian authorities as part of the core Russian mainland and also simultaneously took part in Russia's colonizing efforts elsewhere (at one time, also representing much of the ruling elite of the Soviet Union), which further erodes the case for the notion of Ukraine as colony. The Western part of the country under Habsburg rule, the historian argued, fits the definition of a colony better, although paradoxically it existed in a more liberal political culture. "The Ukrainian case," Hrytsak writes, "represents a wide variety of colonial experiences that are hard to group together under the umbrella of postcolonial theory." ${ }^{4}$ Eventually, he concedes that the Soviet collectivization may have been a form of peasants' "internal colonization," but eventually inscribes the formation of modern Ukraine almost exclusively into a European context, portraying it as a result of intensified continental and global interaction and warfare.

This critique is as difficult to ignore, as it is to accept fully. I argue that much of the intellectual tension around this problem is a result of a particular malentendu that stems from politicizing the issue of whether Ukraine at any given point should be interpreted as a colony; moving away from the question of who colonized whom towards the question of how a modern subject formed within a system of power relations can lead to a more productive problematization of East European post-coloniality. This is an ambitious project to undertake, and this undertaking has been part and parcel of the earliest postcolonial Ukrainian narratives since the 199os. In this article, I take inspiration from Hrytsak's hint of collectivization being a potential colonial enterprise and focus on how various, mostly Soviet discourses constructed Ukrainian subjectivities of the 1920s-1930s. This seems only more relevant in the light of the much more socially and politically charged debate on Ukraine's recent de-communization project. I do hope this article will make a contribution to this debate from a thoroughly elaborated yet refreshing theoretical ground: the ground of postcolonial theory.

\section{Split Subject: From Negative Resistance to Postcolonial Critique}

Postcolonial exploration of subjectivity has developed in dialogue with Michel Foucault who arrived at the theory of the subject as the third major theme of his work (the other two being knowledge and power). In his College de France lectures, Foucault pinpointed the mode of being a subject as the mode of governing oneself and others, thus making it a function of power legitimized by knowledge and knowledge stabilized by power. ${ }^{5}$ This perspective turns the self into a site of power that is self-produced by way of knowledge, a set of practices of the self.

In simpler terms, the subject is produced when it exercises power (mediated by discourse) or when it becomes the object of power, including its own power and knowledge of itself that, through the exercise of certain techniques (such as discipline, self-restraint or effort

3 Ilya Gerasimov and Marina Mogilner, "Deconstructing Integration: Ukraine’s Postcolonial

Subjectivity," Slavic Review 4 (2015): 715-22.

4 Yaroslav Hrytsak, "The Postcolonial is not Enough," Slavic Review 4 (2015): 733.

5 Michel Foucault, The Hermeneutics of the Subject: Lectures at the Collège de France, 1981-1982 (New York: Picador, 2006); Michel Foucault, The Government of Self and Others: Lectures at the Collège de France, 1982-1983 (New York: Picador; Palgrave Macmillan, 2011). 
optimization), is capable of leading to the position of power. We become someone when we speak of others, or are (self)-spoken of, from the position of power, which can only be positioned within what we agree is our knowledge of truth. ${ }^{6}$

This situatedness of subject within language has been developed further by Judith Butler, who suggested that subjectivity is at all possible thanks to a repertoire of norms and practices that the subject receives from society (notably, through language), while the principal citability of language enables the agency of the subject: it is up to us how to construct our roles, from which elements and in which combination; we are who we perform to outsiders. ${ }^{7}$ Likewise, hate speech appears productive rather than restrictive when it comes to the formation of the subject; negative statements affirm the existence of what they criticize and create a backlash against the norm, often tackled by a willing appropriation of the slur accompanied by its reversal. ${ }^{8}$

This poststructuralist, feminist perspective on the subject is very close to the postcolonial frame of reference. Postcolonial theory has made significant advances in its application to Eastern Europe, becoming an increasingly legitimate approach beyond the ground of literary studies that saw its proliferation early on. It is now not uncommon to come across a postcolonial reading of East European experiences not only in literature or history, but also in political and social science, media studies, human geography and other disciplines.

Typologically, it is possible to speak of several currents within the field, focusing on Western colonialism towards Eastern Europe, ${ }^{9}$ Russia's colonialism in Eastern Europe ${ }^{10}$ and

6 My interpretation of Foucault is in large part based on lectures by Sven-Olov Wallenstein, to whom I am much indebted for his condensed yet clear explanations and eye-opening discussions.

7 Judith Butler, Giving Account of Oneself (New York: Fordham University Press, 2005).

8 Judith Butler, Excitable Speech: A Problem of the Performative (New York: Routledge, 1997).

9 Larry Wolff, Inventing Eastern Europe: The Map of Civilization on the Mind of Enlightenment (Stanford: Stanford University Press, 1994); Ezequiel Adamovsky, "Euro-Orientalism and the Making of the Concept of Eastern Europe in France, 1810-188o," Journal of Modern History 3 (2005): 591-628; Aleksander Fiut, "In the Shadow of Empires: Postcolonialism in Central and Eastern Europe: Why not?" in From Sovietology to Postcoloniality: Poland and Ukraine from a Postcolonial Perspective, ed. Janusz Korek (Stockholm: Södertörns högskola, 2007), 33-40; Nataša Kovačević, Narrating Post/ Communism: Colonial Discourse and Europe's Borderline Civilization (London: Routledge, 2008); Fabio Belafatti, “Orientalism Reanimated: Colonial Thinking in Western Analysts' Comments on Ukraine,” Euromaidan Press, accessed January 21, 2016, http://euromaidanpress.com/2014/10/27/westerncommentators-should-rid-themselves-of-old-prejudices-dating-back-from-the-age-of-colonialismbefore-commenting-on-eastern-european-affairs/.

10 Tamara Hundorova, "Postmodernistska fiktsiia Andrukhovycha z postkolonialnym znakom pytannia [Andrukhovych's Postmodern Fiction with a Postcolonial Question Mark]," Suchasnist 9 (1993): 79-83; Tamara Hundorova, "Postcolonial Ressentiment - the Ukrainian Case," in From Sovietology to Postcoloniality: Poland and Ukraine from a Postcolonial Perspective, ed. Janusz Korek (Stockholm: Södertörns högskola, 2007), 103-14; Marko Pavlyshyn, "Shcho peretvoriuietsia v 'Rekreatsiiakh' Yuriia Andrukhovycha? [What Is Recreated in Yurii Andrukhovych's Recreations?]," Suchasnist 12 (1993): 115-45; Ewa Thompson, Imperial Knowledge: Russian Literature and Colonialism (Westport: Greenwood Press, 200o); David Chioni Moore, "Is the Post in Postcolonial the Post- in Post-Soviet? 
in Central Asia, ${ }^{11}$ Poland's imperialism, ${ }^{12}$ and general self-orientalism/internal colonisation by East Europeans..$^{13}$ As incomplete as this overview of this burgeoning field is, it leaves one with an impression, however, that the study of representations and power/knowledge imbalances inherent to postcolonial situations have eclipsed yet another key axis of the problem, that of subjectivity. It is not entirely absent but it seems to be found in a disproportionately small

Towards a Global Postcolonial Critique," PMLA 116 (2001): 111-28; George G. Grabowicz, "The Soviet and the Post-Soviet Discourses of Contemporary Ukraine: Literary Scholarship, the Humanities and the Russian-Ukrainian Interface," in From Sovietology to Postcoloniality: Poland and Ukraine from a Postcolonial Perspective, edited by Janusz Korek (Stockholm: Södertörns högskola, 2007), 61-82; Ola Hnatiuk, "The Negative Auto-Stereotype in Contemporary Ukrainian Discourse on Identity: Some Remarks on the Concept of 'Ukrainian Ghetto," in From Sovietology to Postcoloniality: Poland and Ukraine from a Postcolonial Perspective, edited by Janusz Korek (Stockholm: Södertörns högskola, 2007), 139-54; Janusz Korek, "Central and Eastern Europe from a Postcolonial Perspective," in From Sovietology to Postcoloniality: Poland and Ukraine from a Postcolonial Perspective, edited by Janusz Korek (Stockholm: Södertörns högskola, 2007), 5-22; Janusz Korek, "In the Face of the West and the East - the Formation of the Identity of the Polish Intelligentsia After the End of World War II," in From Sovietology to Postcoloniality: Poland and Ukraine from a Postcolonial Perspective, ed. Janusz Korek (Stockholm: Södertörns högskola, 2007), 229-69; Myroslav Shkandrij, "The Postcolonial Moment in Ukrainian Writing," in From Sovietology to Postcoloniality: Poland and Ukraine from a Postcolonial Perspective (Stockholm: Södertörns högskola, 2007), 83-92; Mykola Riabchuk, “Two Ukraines' Reconsidered: The End of Ukrainian Ambivalence?” Studies in Ethnicity and Nationalism 15 (2015): 138-56; Mykola Riabchuk, "In Bed with an Elephant: Cultural Wars and Rival Identities in Contemporary Ukraine," in From Sovietology to Postcoloniality: Poland and Ukraine from a Postcolonial Perspective, ed. Janusz Korek (Stockholm: Södertörns högskola, 2007), 155-76; Mykola Riabchuk, Dvi Ukrainy: realni mezhi, virtualni viiny [Two Ukraines: Real Borders, Virtual Wars] (Kyiv: Krytyka, 2003); Roman Horbyk, "Paper Empires. Orientalism in the Mediated Portrayals of India and Ukraine: A Case Study of British and Russian Press," East/West 16 (2013): 203-22.

11 Thompson, Imperial Knowledge; David Schimmelpenninck van der Oye, Russian Orientalism: Asia in the Russian Mind from Peter the Great to the Emigration (New Haven: Yale University Press, 2010); Vera Tolz, Russia's Own Orient: the Politics of Identity and Oriental Studies in the Late Imperial and Early Soviet Period (Oxford: Oxford University Press, 2011); Madina Tlostanova, A Janus-Faced Empire. Notes on the Russian Empire in Modernity, Written from the Border (Moscow: Blok, 2003); Madina Tlostanova, "Postsocialist = Postcolonial? On Post-Soviet Imaginary and Global Coloniality," Journal of Postcolonial Writing 2 (2012): 130-42; Madina Tlostanova, "The Imperial-Colonial Chronotope: Istanbul-Baku-Khurramabad," in Globalisation and the Decolonial Option, ed. Walter D. Mignolo and Arturo Escobar (London; New York: Routledge, 2013), 26o-81.

Bogusław Bakuła, "Colonial and Postcolonial Aspects of Polish Discourse on the Eastern 'Borderlands,"' in From Sovietology to Postcoloniality: Poland and Ukraine from a Postcolonial Perspective, ed. Janusz Korek (Stockholm: Södertörns högskola, 2007), 41-6o.

13 Milica Bakić-Hayden, “Nesting Orientalisms: The Case of Former Yugoslavia," Slavic Review 4 (1995): 917-31. 
number of works, mostly within literature studies. Notably, Vitaly Chernetsky ${ }^{14}$ and Tamara Hundorova ${ }^{15}$ have produced sophisticated accounts of a postcolonial subject's transformations in poetry and fiction.

Since early on, the experiences of a subordinated subject have been studied in the most direct and obvious way focusing on colonial trauma, which has made postcolonial narratives susceptible to victimization and one-sided narratives of the liberatory struggle against the forces of evil. At the same time, attempts have been made to reposition the colonial subject as an active agent post-factum, something that did not work very well. ${ }^{16}$ Finally, with the focus on discourse that was brought about by figures such as Edward Said and Stuart Hall, postcolonial theory took a turn towards the study of representations and a power/knowledge dynamic. ${ }^{17}$ This has been a thriving field, but it has taken empirical work based on theory on a different trail where we are supposed to uncover ill-intended misrepresentations and inequalities of status. All this, the way I see the situation, only contributes to diverting efforts away from the study of subjectivity, especially within Ukrainian studies; although if one is to reconsider the premises of Foucauldian critique of modernity, it becomes clear that power, knowledge and subject should best be studied together.

Compensatory intellectual efforts are also nothing new for the communities that have for long been defined as postcolonial. In Africa, Achilles Mbembe argues: "The violence of falsification and material expropriation are said to be the main components of African history's uniqueness and of the tragedy that is at its foundation." 18 This created a sense of historical degradation, and put the desire to overcome it at the heart of African subjectivity. The result of both competing African ideologies, those of nativism and Afroradicalism, is a reified perspective on history that robs Africa of its responsibility and victimizes it as a spoil of foreign predatory forces. The "privileging of victimhood over subjecthood is derived, ultimately, from a distinctively nativist understanding of history — one of history as sorcery." 19

The prevalence of the pre-modern subject (in Africa and Ukraine) is a negative answer to the question of the modern subject. This is what also must be pondered in the quest for a positive answer; how did the situation of "Second World" postcoloniality affect the situation of the Ukrainian subject thinking itself as a modern subject? ${ }^{20}$ The first consequence of such a situation would be a comparative self-perception as incomplete and lacking (in a Lacanian sense?), such as

14 Vitaly Chernetsky, Mapping Postcommunist Cultures: Russia and Ukraine in the Context of Globalization (Montreal: McGill-Queens University Press, 2007).

15 Hundorova, "Postcolonial Ressentiment."

16 The Indian school of subaltern historians criticised by Gayatri Spivak is a notable example.

17 Edward Said, Orientalism (New York: Random House, 20oo); Stuart Hall, "The West and the Rest: Discourse and Power," in The Indigenous Experience: Global Perspectives, ed. Roger Maaka and Chris Andersen (Toronto: Canadian Scholars' Press, 20o6), 165-73; Stuart Hall, "The Spectacle of the Other," in Representation: Cultural Representations and Signifying Practices, ed. Stuart Hall (London: Sage, 1997), 225-87.

18 Achille Mbembe, "African Modes of Self-Writing," Public Culture 14 (2002): 241.

19 Mbembe, "African Modes of Self-Writing," 245.

20 Chernetsky, Mapping Postcommunist Cultures, xvi. 
in the well-known analysis of Indian subjectivity by Dipesh Chakrabarty. The Indian subject is much more directed outwards to the common rather than to the inner, private life, which, when taken in a comparison with a default-mode European perspective, is indeed perceived as a lack. The Indian subject interiorizes the European ideal as the epitome of modernity and develops an awareness of its own present "as the site of disorder" while simultaneously trying to move away from it. ${ }^{21}$ Thus, history becomes a process of splitting itself. At the same time, freedom and emancipation get excluded from this construct as nationalist discourses negotiate their ideal as "truly modern," i.e. benefiting from pragmatic advantages that advanced Western practices give, however, trimming their undesired "selfish," "lenient" and "self-indulgent" effects that threaten the nationalist project of society. The uncritical adoption of this perspective blinds us to what was another part of authentic subjectivity, a set of non-modern ideas and practices. The Indian subject thus is on the one hand split into the subject and the object of history ("modernizing" elites and peasant masses to be modernized) and, on the other hand, speaks from the position of a nation state metanarrative that constitutes a theoretical Europe. This subject can only practice a "mimetic" (Homi Bhabha's term ${ }^{22}$ ) self-representation that positions itself as a modern European subject which, however, because it is not entirely modern and European, looks failing and never complete.

Of course, it is impossible to speak about Ukraine's colonial situation without admitting its ambivalence. On the one hand, Ukrainians were active colonizers of steppes north of the Black Sea populated by Turkic peoples; similarly, Ukrainian cultural and ideological domination over Muscovy in the second of half of the 17th century suspiciously reminds of cultural imperialism. On the other hand, Ukraine was the victim of its own creation. First, the imperial ambitions of medieval Kyiv pushed it northwards establishing principalities that already in pre-Mongol times were challenging its domination. Second, the authority of the Russian Empire over the Hetmanate was only possible because significant parts of its population, elite, and masses, found it conducive to their interests. The very idea of an Orthodox Slavonic empire was born in Kyiv and the empire was built with many Ukrainian hands. ${ }^{23}$ This is not to say that there was no colonization; rather, that Ukraine was no to this and, like in Africa, Asia, and Latin America, colonization was enabled by the local groups interested in it. Like elsewhere around the globe, the unidimensional idea of victimhood is to be rejected. The fact that, for example, locals participated in the colonization of their territory and even co-created it, or were allowed to enter the colonizing elite on certain conditions, or spearheaded the colonization of other lands, is not a contradiction to their postcolonial condition; it is one of its rules. In a similar vein, postcoloniality does not preclude the possibility of the power and agency of the colonized; on the contrary, the empire is shaped and influenced by its colonies just as the colonies are shaped and influenced by the empire. A large part of criticisms against the postcolonial perspective on Eastern Europe originate in a stereotypical "straw man" version thereof, reduced to a one-

21 Dipesh Chakrabarty, "Postcoloniality and the Artifice of History: Who Speaks for 'Indian' Pasts?” Representations 37 (1992): 13.

22 Homi Bhabha, “Of Mimicry and Man: The Ambivalence of Colonial Discourse," October 28 (1984): 126.

23 Yurii Shevelov, “Moskva, Maroseika," in Z istorii nezakinchenoi viiny, ed. Oksana Zabuzhko (Kyiv: Vydavnychyi dim “Kyievo-Mohylianska akademiia," 2009), 63-70. 
dimensional, ideological harangue that has little to do with postcolonial theories of hybridity, subjectivity and subalternity. As Chernetsky argued, based on Ania Loomba, Leela Gandhi and Frantz Fanon's famous pitfall warning, post colonialism should not be reduced to a contestation of colonialism but rather understood as a form of critique that goes beyond the denunciation of the empire towards the deconstruction of "negative resistance" against it. ${ }^{24}$

As a response to this challenge, I situate within the field of postcolonial historical and literary studies of subjectivity the Foucauldian discourse analysis of subjectivity as it was constructed in Soviet Ukraine of the 1920s-1930s.

\section{Fostering Docile Bodies: Soviet Ukrainian Reconstitution of the Subject in the 1920s}

"In order to move forward and, moreover, to succeed in one's work, one has to get knowledge of oneself first of all, namely, to understand the reasons for one's current poverty," wrote the Kyiv-based Nova hromada (New community) magazine in January 1929 (No. 2, 55) addressing its audience of mainly Ukrainian peasants. What this discursive move offered to them was in essence "a technique of the self," specifically, that of self-knowledge equaling the power over self.

It is in popular magazines, with their prescriptive, didactic modes of discourse that the ideology of the desirable subject is spelled out very clearly; for all their simplicity and unpretentiousness, journalists and second rate writers were also rather honest in describing the ideal as marginal or non-existent in reality and in lambasting the authentic subjectivity that had to be broken and refashioned into something new. There was a relative abundance of such periodicals in the Soviet Ukraine between 1922, when the first of them, the already mentioned Nova hromada, published its first issue, and 1935, when Hlobus (The Globe) became the last one to cease publication. These magazines were not projects of the state directly; however, it exercised control over their content through Holovlit's (Glavlit's) sprawling regional network. But it is too simplistic to believe that these periodicals were nothing else than puppets of the authorities. Most of them were established as explicit endeavors to modernize culture and audiences and catch up with the West. Vsesvit (Universe) openly disclosed this was the objective of its founder Vasyl Ellan-Blakytnyi (1928, Nos. 7, 8-9); similarly, Mike Johansen and Levko Kovaliv's intention in Universalnyi zhurnal (Universal magazine) was reported as creating a periodical "of an unknown type in Ukrainian journalism, that of English magazines." 25 While used for propaganda purposes, popular Soviet Ukrainian magazines also provided their staffs with an opportunity to inscribe their own tasks into the statist project, which became characteristic for intellectuals' interaction with the Soviet authorities, as noted by Serhy Yekelchyk. ${ }^{26}$

A systematic review of the magazines demonstrates that one of the key discourses was that of "culture," or the necessity to acquire culture. "Cultured farming," "cultured herding," "cultured

24 Chernetsky, Mapping Postcommunist Cultures, 52-53.

25 Yurii Smolych, "Yohansen," in Rechnyk ukrainskoi kultury. Mike Johansen u spohadakh, lystakh, materialakh, ed. I. M. Lysenko (Kyiv: Rada, 2003), 76.

26 Serhy Yekelchyk, Stalin's Empire of Memory: Russian-Ukrainian Relations in the Soviet Historical Imagination (Toronto: University of Toronto Press, 2004). 
bookselling" etc. are literally omnipresent. Sometimes, the audience's aesthetic education came into focus, especially for more refined, urbane publications such as Universalnyi zhurnal. But when a peasant was said to have "passed the exam for a cultured farmer" (NH, 1928, No. 6), the implications included being efficient, rational, orderly. In both cases, "culture" is constructed as something a Ukrainian subject typically lacks.

In the article I quoted at the beginning of this section, $\mathrm{NH}$ addressed its readers directly. It was a program of sorts, an immediate urge to change towards a "higher cultural level" which presupposed the rational use of wintertime, active participation in civic life, enhancing knowledge (by subscribing to and reading the press, using village libraries, attending courses, etc.), proper hygiene, healthy food and better healthcare, proper childcare, modern communication technology, self-knowledge and time management, politeness, organized and collective entertainment, and Soviet-style gender "equality," understood as burdening women with civic activism. In another article, "cultural growth" is described as a presence of

acommunalfarm(komuna), a tractor unit(kolona), acooperation-involved population, civilized cooperative workers, a well-functioning village club (selbud), literacy, a new lifestyle, and everything that public and self-organization (samodiialnist) can accomplish under the guidance of the party and the Soviet authorities $(N H, 1928$, No. $16,406)$.

With this range of "code words" that describe the program for the new subject, the author invoked its features: collectivism, technological and technical mastery, cultural modernization — and docility.

Docility was predicated not only in terms of ideology or politics but at the corporal level as well, and hygiene functioned as a key bridge here. In a comical short story "Parashchuk, a Good Red Army Soldier" (NH, 1930, No. 3), the protagonist pretends to have been a red guard to get a job and finds himself forced to perform the expected qualities of the modern, reformed subject mainly in the realm of hygiene, which eventually leads to him developing actual positive changes, such as punctuality and tidiness. The "expectation" situation very closely resembles a Foucauldian dispositif, and the performative, mimetic aspect of subjectivity is apparent as the key technique bringing about the reform of the subject. Another aspect of the modern subjectivity sometimes embraced the absence of shame and the acceptance of body (especially in the magazines largely intended for the urban population):

Everyone understands, of course, that [our] children and grandchildren under socialism, trained, strong and handsome, unbroken from the hard physical labor, healthy and aware of their health and beauty, will not be ashamed like us of their bodies, and will be spending their leisure naked and beautiful in the open air and caring sunshine (UZh, 1929, No. 4, 56).

This extended further to an instrumental perspective on the body as a tool of a ballet dancer $(U Z h, 1929$, No. 8, 62-63) or as a biomachine in a $N H$ feature on public recreation entitled "Man Under Repair" (1929, No. 11, 259). 
Technology and technical knowledge served as another aspect of modernity, breaking with the past and constituting the modern subject as "tech-savvy." Machines became tools in the struggle against the old and were often used as means to overcome the irony and sarcasm of peasants (note a parallel in Oleksandr Dovzhenko's The Earth). In a feature "Where a Monastery Stood..." (NH, 1928, No. 17, 455), the modernity of the commune that occupied a former monastery is emphasized through its possession of technology, electricity, and a radio that is envied by the peasants who come to the commune to consume modern media:

They come, sit quietly and listen, closely watching the loudspeaker. And when the broadcast is over and the time comes to go home, they reluctantly stand up and always sigh and regret not having such a 'little talking machine' in their village.

The text makes it clear that the village is still sympathetic to religious practices but the generation of "the new shift" is "being hardened by the commune through correct upbringing and care." The new, modern Soviet subjects shun religion and "instead listen to the radio, read newspapers, magazines, books, they study — they partake of the new culture."

On the surface, the overall position of the magazines may resemble the "modernization without Westernization" tenet. The magazines never forget to criticize the West for capitalist wrongdoings, and often suggest that foreign experience "does not suit us" ( $N H, 1928$, No. 15, 394) because of its individualist, bourgeois character. In the words of one journalist, "the egg trade in England is as speculative and predatory as in the former Russia" (NH, 1928, No. 15, 333). However, the very idea of modernity - and the practices poised for catching up — are constructed as purely Western, based on an idealized view of Europe and North America:

It is on purpose that we illustrate this article with photographs characterizing the lifestyle of American farmers [farmeriv]. Our readers should see how much we must do to equal the technology, welfare, and culture of the Americans, ordinary farmers [khliborobiv] just like us (NH, No. 2, 1928, $\left.5^{6}\right)$.

In essence, progressive practices and techniques were to be directly transplanted from the West, akin to the magazine format itself. In the same way, the transformation of housing or retail was imagined based exclusively on Western examples, such as this praise of Swedish cooperative shops that among other things testifies to the Soviet shops being unhygienic and poorly equipped:

In order to reduce the number of flies in the grocery shops, the windows are constructed in such a way that they have a permanent flow of water over glass. In meat and vegetable shops you will always find wonderful electric refrigerators. Every shop has enough chairs for the customers to sit in front of the counter (NH, No. 2, $1928,44)$. 
In bridging the gap with the West, the subject was constructed as split into the masses, the material to be bent, and the activists who were "sowing knowledge among the peasants," as the Odesa Agricultural Museum did in $N H$ (1928, No. 13, 593). As Shkandrij remarks, some 1920 conflicts stemmed from "the traditional conflict between the intelligentsia and the broad masses"; ${ }^{27}$ the East European troubles with subjectivity indeed date back to this much earlier than the Soviet times setup, so typical of a colonial situation. Even in cities in the 1920s, theatre critics, for example, spoke of "two publics," the more refined and the simpler one to be educated. ${ }^{28}$ Often, the masses accept "education" and act obediently, so "the call [haslo] 'Let's plant a forest!' is responded to by the Lubny region's, 'We are planting a forest!" (1928, No. 13, 593). Perhaps as often, they were portrayed as driven by distinctly unmodern laziness and selfish parochialisms; one text in particular compares their suspicions of the new lifestyle with the fear of a railway; both are "funny and weird" ( $N H, 1928$, No. 13, 359).

Of course, the opposite of Western modernity is constructed as being Asian. In "Asiatic Culture," a short story by the writer Semen Skliarenko (Vsesvit, 1928, Nos. 1, 2-6), a young "uncultured" peasant is shocked by his first encounter with a city. Seduced by a prostitute, he contracts a non-lethal venereal disease but dies when his mother applies a folk treatment to cure him. Both key characters, the mother and son, adopt a local doctor's (a member of the intelligentsia) designation of them as "Asians" and their culture as "Asiatic." Expiring, the son whispers: "I'll die, mother. Like an Asian..."; the heartbroken mother rambles the village as the personified, unreasonable, irrational non-modern subject:

"You are Asians. Asiatic culture [...] arrrgh..."

And she walks through the village on and on. Sloppily clad, dishevelled, mad.

The mother wanders looking for the Asians who took her son.

But the mother is never to find them (Vsesvit, 1928, Nos. 1, 2-6, 6).

"Rozkachalys" (Got Going) by O. Tertus in NH (1928, No. 22, 554-59) narrates the story of a revolutionary troika who arrive in a village as obvious strangers to confiscate weapons with a Russian-language decree and threats of execution. Noting the extent of weapon ownership by peasants at the end of 1928 , seemingly more important is that the peasants in the text act irrationally, as if hiding the weapons out of sheer greed, and are finally broken by the troika's raw power into a rational act of giving up the weapons by secretly throwing them into a semi-defunct well. The cleaning of the long neglected well, which is beneficial to the community, is eventually triggered by this event, and the revelation of this fact provides the story with a comic relief that unites the powerful and somber troika and the peasants in a burst of collective laughter.

This and many other stories construct the mass as oscillating between two artificial narrative constructs, the figures of an outright enemy (kurkul) and of an undecided peasant. The latter was a complex negotiation that reflects, in some way, the actual complexity of the countryside struggles. Even though the undecided may ask something as subversive as "Tell me,

27 Myroslav Shkandrij, Modernists, Marxists and the Nation: The Ukrainian Literary Discussion of the 1920 (Edmonton: Canadian Institute of Ukrainian Studies Press, 1992), 180. 
please, where do they bring this bread that is taken from us? It's said, to Russia; the Bolsheviks will then flee to there too..." ( $N H, 1929$, No. 14, 305), still a potentially "good" type, usually claiming by the end of the plot repeatedly: "Now I know," "Now I understand it well." He can be on good terms with the anti-bolshevik resistance but at the same time cooperate with the authorities and eventually side with them, often on moral grounds (as in "Uncle Mytro's Truth," in Vsesvit, 1928, No. 9). Unlike the undecided figure that constituted the potential for reform, the kurkul was imagined as unable to mimic or perform the conscious, rational and docile subject, and thus was subject to either marginalization or (mostly later) destruction. Of course, the criteria for the kurkul were consciously loose and adjustable; an article "How to recognize a kurkul" gives a range of attributes that make it possible to classify as kurkul anyone who ever offered anything for sale, i.e. literally anyone under the new economic policy, thus making it a floating signifier that could be applied indiscriminately to anyone whom it was practical to designate so:

We are asked in the letter, "How could we find a measure that would enable us to recognize whether or not a given peasant is a kurkul." Such a measure to put to one or the other peasant with the ability to say at once "this is a kurkul," and "that is a middle range peasant," and "that one is a poor one," did not, does not and cannot exist ( $\mathrm{NH}$, 1928, No. 14, 375).

Eventually, the Soviet reconstitution of the Ukrainian subject most likely inspired its critique in Mykola Kulish's insightful Narodnyi Malakhii (People's Malakhii), where it is ridiculed as "the reform of man" put forth by a half-deranged postmaster and represented as a highly destructive practice (self-evidently, for re-construction requires the destruction of what has already been).

\section{Outside Lenin's Shadow: A Comparative Discussion}

This perspective on discourses found in the popular Soviet Ukrainian press of the 1920 and 193os suggests that, regardless of how we solve the question of the Ukrainian situation as a colonial situation, the nation's intellectuals were concerned with fairly similar problems to those that troubled intellectuals in India, Algeria, or South Africa. Ukrainian subjectivity was seen as deficient and incomplete, and in an acute need of restructuring according to the bolshevist agenda. The nation was split into the modernizing elite and the masses to be modernized, and most templates, in spite of the stringent critique of the West, were Western borrowings. The new, modern subject was instructed in techniques of (self-) knowledge, technology use, hygiene, and above all (self-) discipline, whose other side was docility. Those unwilling to conform were condemned to the past and non-being (very often forcefully, as other developments remind). But this was the situation of the state-controlled press; perhaps in more intellectually ambitious circles, or beyond the Soviet Union indeed, the Ukrainian subject was constructed otherwise, without the unpleasant colonial undertones?

I welcome the reader to take a look at the émigré nationalist circles of the 1920 s and 1930s. The conflict between the bolshevist project and the peasants was well noted by Dmytro 
Dontsov, who in his 1921 "Foundations of Our Policy" called to capitalize on the political and emotional split between them to create a petty-bourgeois peasant republic. Dontsov evolved ideologically but at all times he remained committed to slamming the inert intellectualist elites and lauding the peasants' readiness to go to battle for their interests. ${ }^{29}$ Eventually, he would see the situation exactly the opposite of his socialist opponents by introducing a race-theory-based meta distinction between the knightly (Faustian, Nordic) and the subservient (fellah, Eastern) groups best understood as racialized castes, the past successes of Ukrainians connected to the prevalence of the former, the contemporary failures to its demise that had to be reversed. ${ }^{30}$ Dontsov's conservatism seems anti-modern and turned toward the past, but, as many extreme right-wing ideologues, he is a modernist who preaches a revolutionary change to the current miserable condition, a conservative revolution. ${ }^{31}$ Dontsov is a modernist who substituted progress that is socialism's empty signifier, to speak in Ernesto Laclau's terms, - the absent political ideal to strive for - with a return to the past as progress' ultimate objective. The key to political success, as Dontsov explicitly states it, is entirely in the realm of psychology; in this way, the reform of nation is defined explicitly as the reform of subject. Therefore, the issue of political evolution becomes that of modernizing - Westernising, indeed - the community, by fostering a number of traits common to past and contemporary regimes ideal for Dontsov (such as Hitler's Germany or Mussolini's Italy). The subject is again split, this time eternally: the community must create its own lords that will continue to rule the multitude of forever subservient subjects. This was to happen thanks to introducing a range of techniques of the self, such as self-discipline, immoralism, cruelty, emotional solidarity with one's own, and equally emotional rejection of everything ethnically and culturally alien. Dontsov is a classical anticolonial nationalist who only reaffirms colonialism: he constructs the indigenous subject as "the site of disorder" (Chakrabarty), not a "sovereign subject" (Spivak), and comes up with a project to refashion it by a certain (European) standard, which is a completely top-down project. In this point, Dontsov's and thebolshevists' projects coincide: the extremes have met once again.

Back in Soviet Ukraine, Mykola Khvylovyi felt he was compelled to respond to this project with a truly leftist and national version of the reform of the Ukrainian subject, but in essence he could only reaffirm its profound deficiency, which should have been improved by an injection of the same good old elitism and "psychological Europe." And if one is to look at other projects of the time, such as Mykola Zerov's orientation towards European cultural benchmarks and attacks on provincialism or Viacheslav Lypynskyi's moderate conservatism, were they not driven by the same impulse, the perceived profound disorder of a spellbound colonial subject whose defeats and failures were always supposed to be for a reason?

29 Dmytro Dontsov, Pidstavy nashoi polityky [Foundations of Our Policy] (New York: Dnipro, 1957), 200-10. Dmytro Dontsov, Dukh nashoi starovyny [The Spirit of Our Antiquity] (Drohobych: Vidrodhzennia, 1991), 218-38. 


\section{Bibliography}

Adamovsky, Ezequiel. "Euro-Orientalism and the Making of the Concept of Eastern Europe in France, 1810-1880." Journal of Modern History 3 (2005): 591-628.

Bakić-Hayden, Milica. "Nesting Orientalisms: The Case of Former Yugoslavia." Slavic Review 4 (1995): 917-31.

Bakuła, Bogusław. "Colonial and Postcolonial Aspects of Polish Discourse on the Eastern 'Borderlands." In From Sovietology to Postcoloniality:Poland and Ukraine from a Postcolonial Perspective, edited by Janusz Korek, 41-6o. Stockholm: Södertörns högskola, 2007.

Belafatti, Fabio. "Orientalism Reanimated: Colonial Thinking in Western Analysts' Comments on Ukraine." Euromaidan Press. Accessed January 21, 2016. http://euromaidanpress. com/2014/10/27/western-commentators-should-rid-themselves-of-old-prejudices-datingback-from-the-age-of-colonialism-before-commenting-on-eastern-european-affairs/.

Bhabha, Homi. "Of Mimicry and Man: The Ambivalence of Colonial Discourse." October 28 (1984): 125-33.

Butler, Judith. Excitable Speech: A Problem of the Performative. New York: Routledge, 1997.

Butler, Judith. Giving Account of Oneself. New York: Fordham University Press, 2005.

Chakrabarty, Dipesh. "Postcoloniality and the Artifice of History: Who Speaks for 'Indian' Pasts?" Representations 37 (1992): 1-26.

Chernetsky, Vitaly. Mapping Postcommunist Cultures: Russia and Ukraine in the Context of Globalization. Montreal: McGill-Queens University Press, 2007.

Dontsov, Dmytro.Dukhnashoistarovyny [The Spirit of Our Antiquity]. Drohobych:Vidrodhzennia, 1991.

Dontsov, Dmytro. Pidstavy nashoi polityky [Foundations of Our Policy]. New York: Dnipro, 1957.

Dontsov, Dmytro. Natsionalizm [Nationalism]. Lviv: Nove zhyttia, 1926.

Fanon, Frantz. The Wretched of the Earth. London: Penguin, 1963.

Fanon, Frantz. Peau noire, masques blancs. Paris: Éditions de Seuil, 1975.

Fiut, Aleksander. "In the Shadow of Empires: Postcolonialism in Central and Eastern Europe: Why not?" In From Sovietology to Postcoloniality: Poland and Ukraine from a Postcolonial Perspective, edited by Janusz Korek, 33-40. Stockholm: Södertörns högskola, 2007.

Foucault, Michel. The Hermeneutics of the Subject: Lectures at the Collège de France,1981-1982. New York: Picador, 2006.

Foucault, Michel. The Government of Self and Others: Lectures at the Collège de France, 1982-1983. New York: Picador; Palgrave Macmillan, 2011.

Gerasimov, Ilya, and Marina Mogilner. "Deconstructing Integration: Ukraine's Postcolonial Subjectivity." Slavic Review 4 (2015): 715-22.

Grabowicz, George G. "The Soviet and the Post-Soviet Discourses of Contemporary Ukraine: Literary Scholarship, the Humanities and the Russian-Ukrainian Interface." In From Sovietology to Postcoloniality: Poland and Ukraine from a Postcolonial Perspective, edited by Janusz Korek, 61-82. Stockholm: Södertörns högskola, 2007. 
Hall, Stuart. “The West and the Rest: Discourse and Power." In The Indigenous Experience: Global Perspectives, edited by Roger Maaka and Chris Andersen, 165-73. Toronto: Canadian Scholars' Press, 2006.

Hall, Stuart. "The Spectacle of the Other." In Representation: Cultural Representations and Signifying Practices, edited by Stuart Hall, 225-87. London: Sage, 1997.

Hnatiuk, Ola. "The Negative Auto-Stereotype in Contemporary Ukrainian Discourse on Identity: Some Remarks on the Concept of “Ukrainian Ghetto." In From Sovietology to Postcoloniality: Poland and Ukraine from a Postcolonial Perspective, edited by Janusz Korek, 139-54. Stockholm: Södertörns högskola, 2007.

Horbyk, Roman. "Paper Empires. Orientalism in the Mediated Portrayals of India and Ukraine: A Case Study of British and Russian Press." East/West 16 (2013): 203-22.

Hrytsak, Yaroslav. "The Postcolonial is not Enough." Slavic Review 4 (2015): 732-37.

Hundorova, Tamara. "Postmodernistska fiktsiia Andrukhovycha z postkolonialnym znakom pytannia [Andrukhovych's Postmodern Fiction with a Postcolonial Question Mark]." Suchasnist 9 (1993): 79-83.

Hundorova, Tamara. "Postcolonial Ressentiment - the Ukrainian Case." In From Sovietology to Postcoloniality: Poland and Ukraine from a Postcolonial Perspective, edited by Janusz Korek, 103-14. Stockholm: Södertörns högskola, 2007.

Korek, Janusz. "Central and Eastern Europe from a Postcolonial Perspective." In From Sovietology to Postcoloniality: Poland and Ukraine from a Postcolonial Perspective, edited by Janusz Korek, 5-22. Stockholm: Södertörns högskola, 2007.

Korek, Janusz. "In the Face of the West and the East — the Formation of the Identity of the Polish Intelligentsia After the End of World War II." In From Sovietology to Postcoloniality: Poland and Ukraine from a Postcolonial Perspective, edited by Janusz Korek, 229-69. Stockholm: Södertörns högskola, 2007.

Kovačević, Nataša. Narrating Post/Communism: Colonial Discourse and Europe's Borderline Civilization. London: Routledge, 2008.

Mbembe, Achille. "African Modes of Self-Writing." Public Culture 14 (2002): 239-73.

Moore, David Chioni. "Is the Post in Postcolonial the Post- in Post-Soviet? Towards a Global Postcolonial Critique." PMLA 116 (2001): 111-28.

Pavlyshyn, Marko. "Shcho peretvoriuietsia v 'Rekreatsiiakh' Yuriia Andrukhovycha? [What Is Recreated in Yurii Andrukhovych's Recreations?].” Suchasnist 12 (1993): 115-45.

Riabchuk, Mykola. “Two Ukraines' Reconsidered: The End of Ukrainian Ambivalence?” Studies in Ethnicity and Nationalism 15 (2015): 138-56.

Riabchuk, Mykola. "In Bed with an Elephant: Cultural Wars and Rival Identities in Contemporary Ukraine." In From Sovietology to Postcoloniality: Poland and Ukraine from a Postcolonial Perspective, edited by Janusz Korek, 155-76. Stockholm: Södertörns högskola, 2007.

Riabchuk, Mykola. Dvi Ukrainy: realni mezhi, virtualni viiny [Two Ukraines: Real Borders, Virtual Wars]. Kyiv: Krytyka, 2003.

Said, Edward. Orientalism. New York: Random House, 2000.

Schimmelpenninck van der Oye, David. Russian Orientalism: Asia in the Russian Mind from Peter the Great to the Emigration. New Haven: Yale University Press, 2010. 
Shevelov, Yurii. "Moskva, Maroseika." In Z istorii nezakinchenoi viiny, edited by Oksana Zabuzhko, 63-70. Kyiv: Vydavnychyi dim "Kyievo-Mohylianska akademiia," 2009.

Shkandrij, Myroslav. "The Postcolonial Moment in Ukrainian Writing." In From Sovietology to Postcoloniality: Poland and Ukraine from a Postcolonial Perspective, edited by Janusz Korek, 83-92. Stockholm: Södertörns högskola, 2007.

Shkandrij, Myroslav. Modernists, Marxists and the Nation: The Ukrainian Literary Discussion of the 1920s. Edmonton: Canadian Institute of Ukrainian Studies Press, 1992.

Smolych, Yurii. "Yohansen." In Rechnyk ukrainskoi kultury. Mike Johansen u spohadakh, lystakh, materialakh, edited by I. M. Lysenko, 49-91. Kyiv: Rada, 2003.

Snyder, Timothy. "Integration and Disintegration: Europe, Ukraine and the World." Slavic Review 4 (2015): 692-707.

Spivak, Gayatri Chakravorti. “Can the Subaltern Speak?" In The Postcolonial Studies Reader, edited by B. Aschcroft, G. Griffiths and H. Tiffin, 28-37. London; New York: Routledge, 2006.

Thompson, Ewa. Imperial Knowledge: Russian Literature and Colonialism. Westport: Greenwood Press, 2000.

Tlostanova, Madina. A Janus-Faced Empire. Notes on the Russian Empire in Modernity, Written from the Border. Moscow: Blok, 2003.

Tlostanova, Madina. "Postsocialist $\neq$ Postcolonial? On Post-Soviet Imaginary and Global Coloniality." Journal of Postcolonial Writing 2 (2012): 130-42.

Tlostanova, Madina. "The Imperial-Colonial Chronotope: Istanbul-Baku-Khurramabad." In Globalisation and the Decolonial Option, edited by Walter D. Mignolo and Arturo Escobar, 26o-81. London; New York: Routledge, 2013.

Todorova, Maria. "On Public Intellectuals and Their Conceptual Frameworks." Slavic Review 4 (2015): 708-14.

Tolz, Vera. Russia's Own Orient: The Politics of Identity and Oriental Studies in the Late Imperial and Early Soviet Period. Oxford: Oxford University Press, 2011.

Wolff, Larry. Inventing Eastern Europe: The Map of Civilization on the Mind of Enlightenment. Stanford: Stanford University Press, 1994.

Yekelchyk, Serhy. Stalin's Empire of Memory: Russian-Ukrainian Relations in the Soviet Historical Imagination. Toronto: University of Toronto Press, 2004.

Roman Horbyk was born in Kyiv, where he began his studies before obtaining a joint Erasmus Mundus MA from the Universities of Aarhus and Hamburg (2012). He also holds a Candidate of Sciences degree from Taras Shevchenko Kyiv National University (2015) and is currently finishing his doctoral dissertation at Södertörn University (Stockholm, Sweden) on the construction of Europe in the public discourses of Ukraine, Russia, and Poland during Euromaidan. His academic interests are focused on media history and media archeology, language and postcolonial theory, and the history of ideas in Eastern Europe. Roman Horbyk is co-editor of a forthcoming book Against All Odds: Ukraine and Ukrainian Studies after Yuriy Shevelov (with Niklas Bernsand). Roman is also active as a playwright and screenwriter. 